\title{
Spatial Analysis of Human Settlement Expansion Rate in Nigeria: A Case Study of Akure Per-Urban Locations
}

\author{
Oguntade Aanuoluwapo Aderonke \\ Department of Architecture, Federal University of Technology, Akure, Nigeria \\ Email address: \\ oguntadeaanu@gmail.com

\section{To cite this article:} \\ Oguntade Aanuoluwapo Aderonke. Spatial Analysis of Human Settlement Expansion Rate in Nigeria: A Case Study of Akure Per-Urban \\ Locations. American Journal of Environmental Protection. Vol. 9, No. 1, 2020, pp. 10-21. doi: 10.11648/j.ajep.20200901.12
}

Received: January 28, 2020; Accepted: February 18, 2020; Published: February 25, 2020

\begin{abstract}
The purpose of this research is to study the rate of horizontal expansion of human settlement in Akure from 2007 to 2018 with focus on three peri-urban locations that has experienced massive growth in most recent times. Efforts were made to make predictions of possible expansion for the next 20 to 32 years in these areas. To achieve the objectives of this research Google earth images were obtained for all three selected locations for the years 2007 and 2018. For the three locations the same square area was maked out for analysis. The area covered by human settlement for the years 2007 and 2018 was obtained for all three locations using the polygon tool on Google earth. Futher mathematical calculations were done to help determine the rate of horivontal settlements between the two time periods. Calculations were also done to predict the rate of future expansion in all three locations. The results shows that built up area in the three selected locations is rapidly expanding, as a result large vegetation are lost. Predictions show that Akure is tending towards a fully developed conurbation. It concludes by affirming that there is a need to adopt the use of sustainable high-rise mixed-use buildings as a better approach to the current trend of human settlement in Nigeria based on low-rise structures and continuous deforestation to make rooms for new settlements.
\end{abstract}

Keywords: High-rise, Horizontal Expansion Land Use, Sustainable Urban Growth

\section{Introduction}

Land is required for various uses, it is a major factor of production and a fundamental component in the socioeconomic progress of any country or society [1]. Given the competing demands for land, it is essential to plan the use of the available land. Land use planning is a process which helps in achieving physical developments that are orderly, functional, livable and sustainable [2]. The allocation of land between competing alternative uses must take care of the present and future users of land. At the heart of land use planning is therefore sustainable development. According to Brundtland Commission report, sustainable development implies ensuring that the welfare of today's generation is met without compromising the welfare of the future generations [3].

The National Population Commission and National Bureau of Statistics Estimates, puts the forecast for Nigeria's population in 2016 at 193.3 million [4]. It has been estimated that Nigeria's population is bound to double within 20 years and increase three fold by 2050 if Nigeria continues to grow at a $3.2 \%$ rate of the last census [5]. This shows that on a long term basis horizontal expansion of land use may not be sustainable. The welfare of the future generations may be compromised by unplanned use of the available land. One of the major effects of unplanned utilization of land is seen in the pattern of human settlements. This paper sets out to analyze the pattern of human settlements in urban areas Nigeria. Akure city was used as the case study. Specifically, this paper presents the outcome of the determination of the rate of horizontal expansion of human settlements in selected peri-urban locations in Akure, Ondo State, Nigeria and a projected horizontal expansion of human settlements in the city based on the current rate.

It is an established fact that land is a valuable resource. Nigeria however, is a nation with an ever-increasing population and thus the demand for buildings for various purposes is ever increasing. In a bid to meet the demand and need for buildings, the government and private individuals continually clear large land areas for various developmental 
projects. The buildings that usually emerge from these constructions, however, are usually low-rise buildings which occupy large horizontal land area, and each new unit can only serve limited number of people thus necessitating the clearing of more land as the population increases. This implies that green vegetation is being lost over time due to these unplanned building constructions. City expansions are hence contributing to the loss of forest cover with its expected consequences for climate change. There is hence a need to research into what the rate of the horizontal expansion of the cities is and what the expansion is likely to be in the future based on the current rate of horizontal expansion.

\section{Literature Review}

Land cover has been defined as the physical and biological covering or spatial distribution of the land surface, which have been classified into vegetation, bare soil, water, artificial structures and rocks $[6 ; 7 ; 8]$. Land use on the other hand refers to the function land serves (for shelter, recreation, food production, mining), it refers to the way various land resources are put to use and are managed [6;7]. Human settlement is a collection of dwellings where human beings live, it shows how land is put to use for roads, houses, various infrastructure and many other purposes as well as the social relationships of man $[9 ; 10]$. The study of human settlement therefore focuses on human population clusters, to determine their origin, how they evolve, what sustains them, and to predict their growth pattern [9].

Various research has been carried out to determine the rate of land use and land cover change in various urban centers in Nigeria. Research has been carried out by [11] in 2014 on Ibadan, by [12] in 2019 on Abuja, by [13] in 2018 on Warri, by [14] in 2019 on Kaduna, and many more urban centers in Nigeria. Results from the research carried out on these urban centers show that built up area has progressively increased through time at the expense of agricultural land. The results also show that built up areas has gradually expanded from the city center outwards towards peri-urban locations. One of the major drivers for this massive horizontal expansion of human settlement is the rapid increase in population growth. People tend to settle away from the city center as accommodation is more expensive at the city center.

In a bid to determine the rate of land use and land cover change in Nigerian urban centers Akure has not been left out. A research was carried out by [15] in 2015 titled 'Analysis of Akure Urban Land Use Change Detection from Remote Imagery Perspective'. Aerial Imagery Overlay (AIO) was the major data collection tool used. The aim of the research was to determine the change that had taken place in Akure since its creation in 1976. The research collected data spanning three decades from 1985-1994, 1995-2004, 2005-2014. The land use for the research was classified into built up area, thick vegetation, light vegetation and water bodies. The result of the research showed a steady and uncontrolled increase in the expansion of built up area and a dire reduction in thick vegetation. From the results it was observed that expansion was majorly towards the north and eastern parts between 1985 and 2002 and north western parts as at the time of the research. The predictions for expansion shows Akure tending towards a fully grown conurbation by 2034 .

The purpose of this research is to carry out a study on the rate of horizontal expansion in Akure in the more recent years with focus on the north western and north eastern parts of Akure which have been identified by [15] to be experiencing expansion. It is very important to have current information of the status of growth in these areas as this will inform relevant authorities about the rate at which Akure is tending toward conurbation. This research focuses on three areas FUTA South gate/ Apatapiti (north western part of Akure), FUTA North gate (north western part of Akure) and Oba Ile (north eastern part of Akure). Both FUTA South gate/ Apatapiti and FUTA North gate has been growing rapidly and will continue to grow, this is because of the presence of the Federal University of Technology, Akure [15]. As at the time of the research by [15] the growth around the university was flowing into Ibule and Ipinsa, as students and staff of the Federal University of Technology, Akure seek cheaper accommodation to these areas. The study of this change in land use for human settlement should therefore be a continuous one to assist in proper planning for the future.

\section{Methodology}

In a research by [13] an extensive study was done on the various land use and land cover change studies carried out in Nigeria over the Years to determine the various methods of data collection and their results. Out of 35 studies on land use and land cover change analyses only one made use of google earth images, the predominant means of obtaining images were from global land cover facility (GLCF) [13]. Free satellite images obtained from GLCF, however, has certain limitations [16]. These free images are usually of low to medium resolution, to obtain images of high resolution researcher would have to procure such satellite images which can be expensive [16]. It can also be difficult to obtain satellite images for more recent years from GLCF [16].

Google earth images have been studied and proven to have great potentials for use in the study of land use and land cover change. Google earth provide high resolution images with spatial resolution less than $1 \mathrm{~m}$ [16]. In addition to this google earth images can be obtained for the current year as well as for previous years. The images obtained from google earth can be analyzed more critically for various information using GIS softwares such as ArcGIS, ENVI, ERDAS IMAGINE, etc. [16]. However, Google earth can be used without GIS to determine temporal and spatial land use change [17] which is what was adopted in this research. The method adopted in this research is simple and can carried out by anyone who does not have GIS softwares or does not know how to use GIS softwares.

For the purpose of this research, Akure the capital of Ondo State was taken as a case study. From Akure, three different 
peri-urban locations were purposively selected for observation. This was done in order to measure the rate at which human settlements in the city was expanding over time as the peri-urban locations are transformed into urban ones. This will be indicative of the rate of expansion of similar cities in Nigeria over the period selected for consideration. The land use for this research is classified into built up area and unbuilt up area.

In order to determine the rate of horizontal expansion of human settlement in Akure, historical images were obtained from Google earth for the three selected locations in Akure. The images were defined for a total of 13,000,000 square metre for each of the three locations and two time periods. The 13,000,000 square metre was represented by the red circle. Thereafter, the area covered by settlement as at 2007 was obtained through the use of the polygon tool on Google Earth and by carrying out calculations. Likewise, the area covered by the horizontal settlement for 2018 was obtained.

The square area of the spaces occupied by human settlement for the three locations was obtained for each of the six images. The difference between areas occupied by human settlements for the two-time periods were determined. The rate of horizontal expansion for the three different locations was determined as:

$$
\text { Horizontal Expansion Rate }=\frac{\text { Area occupied by Human Settlement in 2018-Area occupied by Human Settlement in } 2007}{2018-2007}
$$

Akure that was used as a case study is in the South Western part of Nigeria. It is the administrative capital of Ondo State. It is situated between latitude $7^{\circ} 15^{\prime}$ and $7^{\circ} 17^{\prime} \mathrm{N}$ and longitude $5^{\circ} 14$, and $5^{\circ} 15^{\prime} \mathrm{E},[15]$. Akure's population has grown from 340,021 in 2006 to an estimated population of 486,300 in 2016, this implies that 146,279 number of people were added to the population in ten years, [18]. The three selected areas within Akure for this research are referred to as FUTA South gate/ Apatapiti, FUTA North gate and Oba Ile.

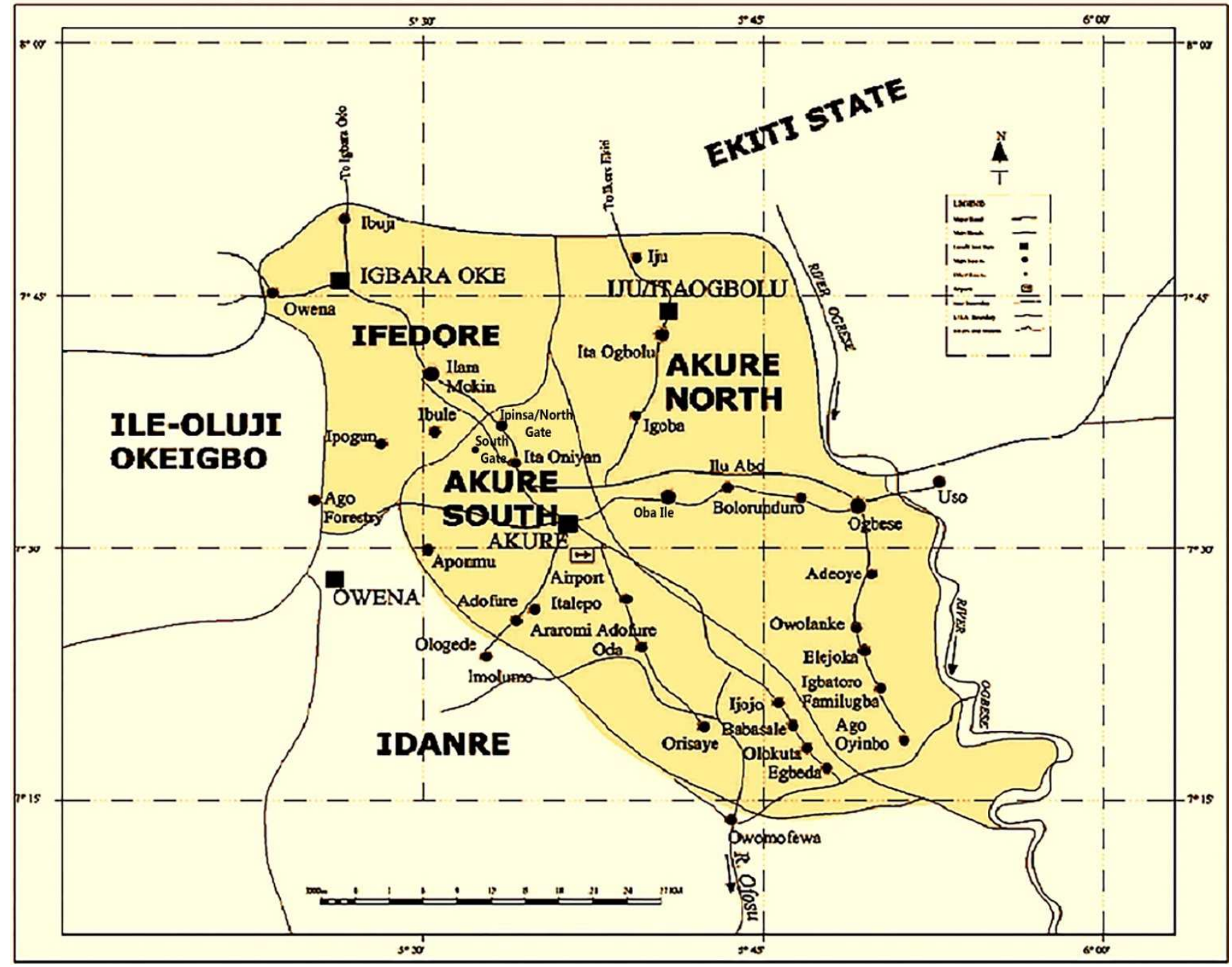

Source: Ministry of Works Akure (edited by Athour), 2020.

Figure 1. Map of Akure south and Akure North. 


\section{Results}

Figures 2 to 7 are images captured from Google earth; those in white represents spaces not covered by buildings. The various marked out places were done to make it easier to identify visually the rate of horizontal expansion as well as to help with the calculation of horizontal expansion. Those in yellow highlights the places occupied by human settlements as at 2007.

\subsection{FUTA South Gate, Akure (2007)}

Figure 2 is the Google Earth image of FUTA South
Gate as at 2007. The area of interest is defined by the circle covering a total of $13,000,000$ square metre. The human settlement area (labelled A) is enclosed in ambercolored polygon. Inside the polygon, two areas without human settlement (labelled B and C) are enclosed. The estimated size of the three areas of interest are presented in Table 1. The table indicates the area covered by human settlement at the FUTA South Gate as at 2007 was $4,374,202$ sq. $m$ which is $33.65 \%$ of the area of interest.

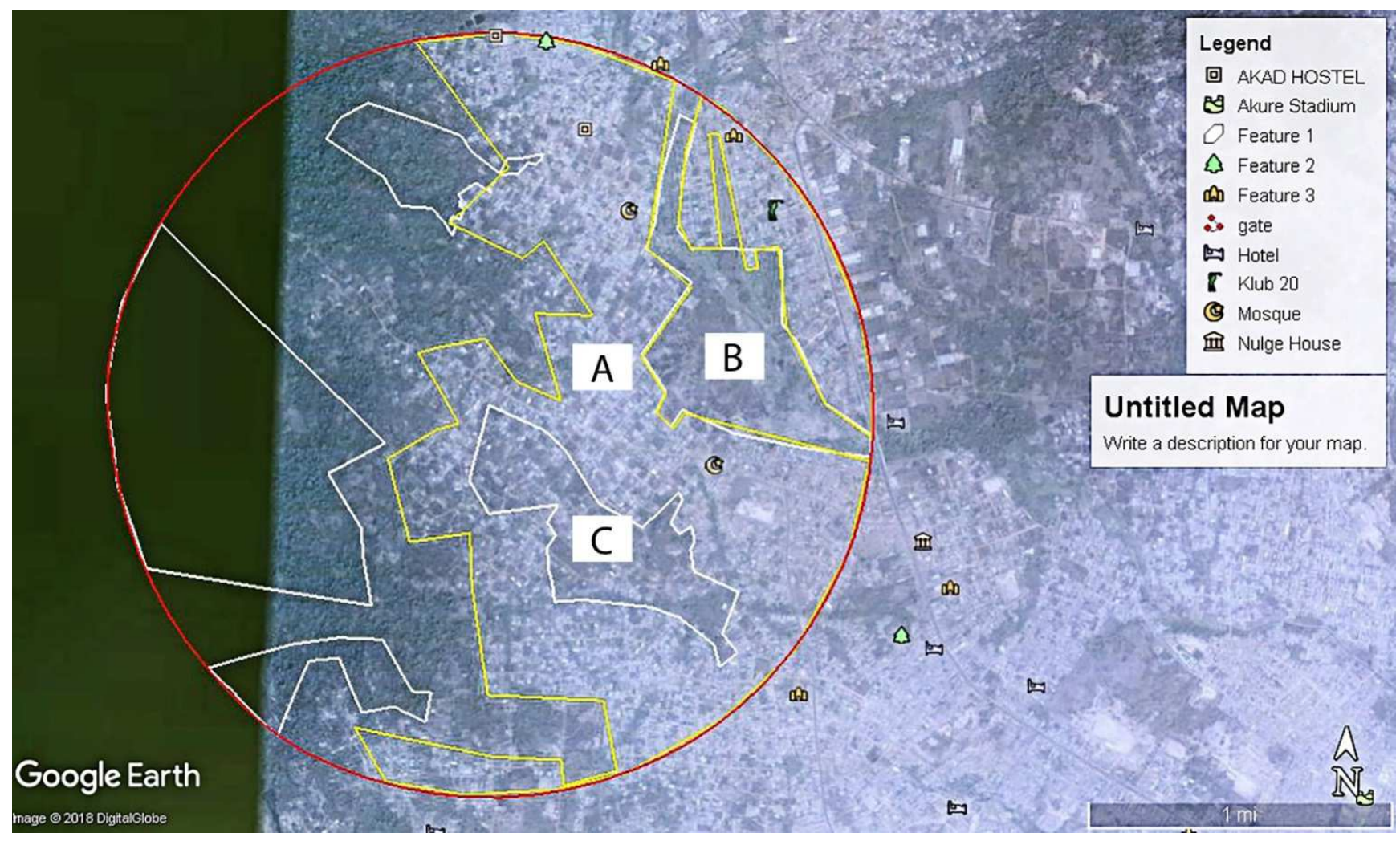

Source: Google Earth, 2018.

Figure 2. Settlement Partern, South Gate FUTA (2007).

Table 1. Analysis of Human Settlement, FUTA South Gate, Akure (2007).

\begin{tabular}{lll}
\hline Description & No & Size (square metre) \\
\hline Total Area Sampled at FUTA South Gate & 1 & $13,000,000$ \\
Area A - Built up Area with un-built up areas embedded & 2 & $5,701,893$ \\
Area B - Un-built up area embedded in "A" & 3 & 647,449 \\
Area C - Un-built up area embedded in "A" & 4 & 680,242 \\
Land area covered by human settlement & $(2-(3+4))$ & $4,374,202$ \\
Percentage of built up area & {$[(2-(3+4)) / 1]^{*} 100$} & $33.65 \%$ \\
\hline
\end{tabular}

Source: Researcher's calculations, 2018.

\subsection{FUTA South Gate, Akure (2018)}

Figure 3 is the Google Earth image of FUTA South Gate as at 2018. The same area of interest in Figure 2 defined by the circle covering a total of $13,000,000$ square metre was covered. The areas devoid of human settlement (labelled D, E, F and G) are separately enclosed and labelled. The rest of the encircled area was already occupied by human settlement; this area was estimated as the difference between the encircled area $(13,000,000$ sq. m) and the polygons D, E, $\mathrm{F}$ and $\mathrm{G}$. Table 2 presents this analysis and it shows that the area covered by human settlement in 2018 was $9,800,899$ sq. $\mathrm{m}$ which is $75.39 \%$ of the area of interest. 
Table 2. Analysis of Human Settlement, FUTA South Gate, Akure (2018).

\begin{tabular}{lll}
\hline Description & No & Size (square metre) \\
\hline Total Area Sampled at FUTA South Gate & 1 & $13,000,000$ \\
Area D - Un-built up area & 2 & $1,810,661$ \\
Area E - Un-built up area & 3 & 825,404 \\
Area F - Un-built up area & 4 & 296,256 \\
Area G - Un-built up area & 5 & 266,750 \\
Land area covered by human settlement & $(1-(2+3+4+5))$ & $9,800,899$ \\
Percentage of built up area & {$[(1-(2+3+4+5)) / 1]^{*} 100$} & $75.39 \%$ \\
\hline
\end{tabular}

Source: Researcher's calculations, 2018.

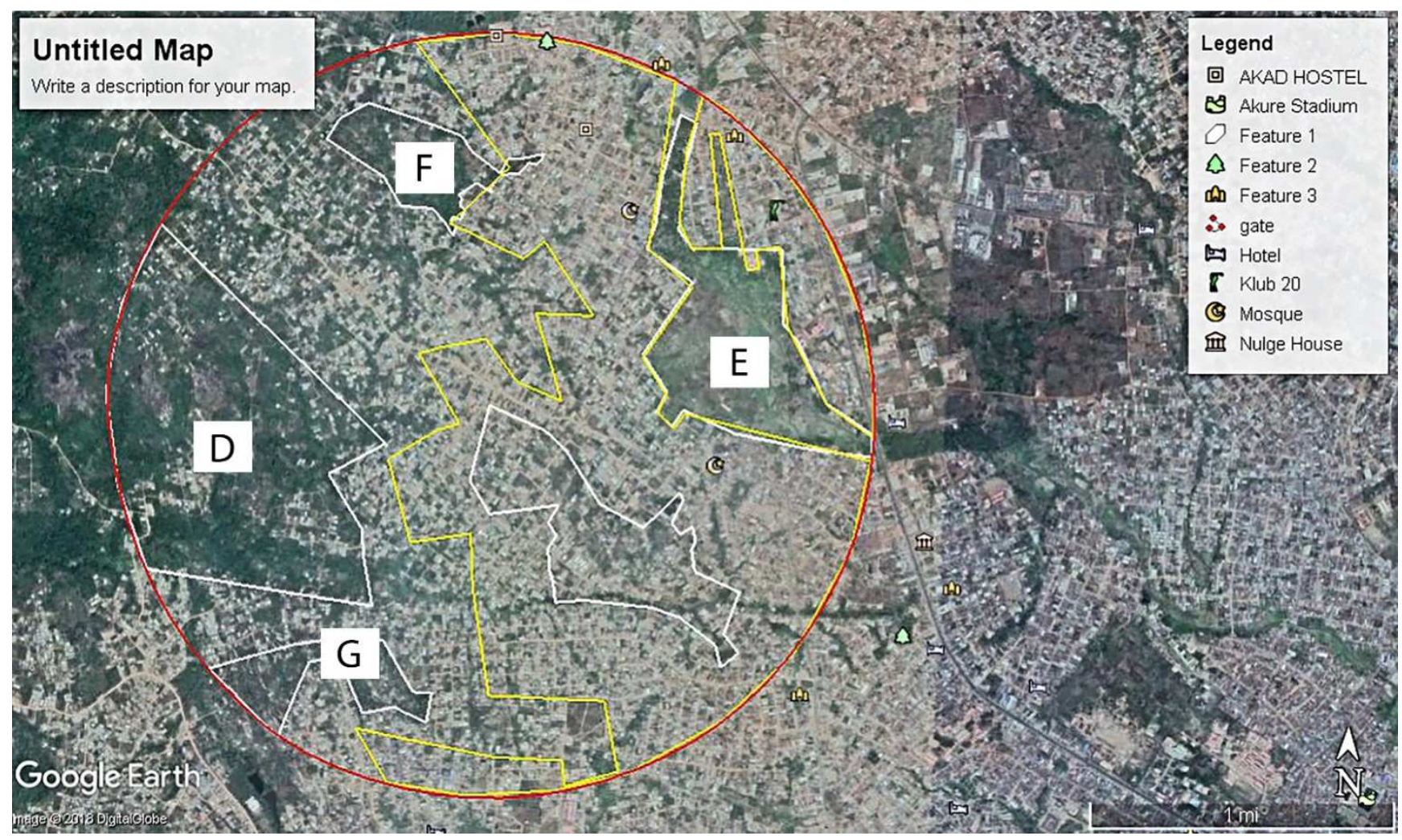

Source: Google Earth, 2018.

Figure 3. Settlement Partern, South Gate FUTA (2018).

\subsection{Horizontal Expansion in FUTA South Gate}

The total area sampled is $13,000,000$ sq. m; as at 2018 a total of $9,800,899$ sq. m. has been built up as human settlement whereas the area built-up as human settlement in 2007 was 4,374,202 sq.m. Thus, the horizontal expansion between 2007 and 2018 was 5,426,697 sq.m. The rate of horizontal expansion of human settlement at South Gate FUTA between 2007 and 2018 is 493,336.09 sq. m/yr. Based on the projection of horizontal expansion in Table 3, by 2038 (20 years from 2018), horizontal expansion would have led to the conversion of additional 9,866,721.81 sq. $\mathrm{m}$ into human settlement making a total of $19,667,620.81$ sq. $\mathrm{m}$ as human settlement. This is $6,667,620.81$ sq. $\mathrm{m}$ in excess of the sampled area of $13,000,000$ sq. $m$ at FUTA South Gate. The implication of this is that the area around the FUTA South Gate would be totally built up by 2038 if the current rate of horizontal expansion is maintained. Projected increase of horizontal expansion of human settlement for 2050 is $15,786,754.88$ sq. $\mathrm{m}$. This result confirms the need to formulate and implement policies to reduce the rate of horizontal expansion.

Table 3. Analysis of Horizontal Expansion, FUTA South Gate, Akure.

\begin{tabular}{lll}
\hline Description & No & Size (square metre) \\
\hline Total Area Sampled at FUTA South Gate & 1 & $13,000,000$ \\
Land area covered by human settlement in 2007 & 2 & $4,374,202$ \\
Land area covered by human settlement in 2018 & 3 & $9,800,899$ \\
Horizontal expansion of human settlement between 2007 and 2018 & $(3-2)$ & $5,426,697$ \\
\hline
\end{tabular}




\begin{tabular}{lll}
\hline Description & No & Size (square metre) \\
\hline Rate of horizontal expansion of human settlement at South Gate FUTA between 2007 and 2018 & $((3-2) / 11 \mathrm{yrs}$ ) & $493,336.09$ sq. m/yr. \\
Rate of horizontal expansion of human settlement at South Gate FUTA between 2007 and 2018 & 4 & $493,336.09$ sq. m/yr. \\
Projected increase of horizontal expansion of human settlement for the next 20 yrs. (that is 2038) & $(4 * 20$ yrs.) & $9,866,721.81$ \\
Projected increase of horizontal expansion of human settlement for the next 32 yrs. (that is 2050) & $(4 * 32$ yrs.) & $15,786,754.88$ \\
\hline
\end{tabular}

Source: Researcher's calculations, 2018.

\subsection{Oba Ile, Akure (2007)}

Figure 4 is the Google Earth image of Oba Ile as at 2007. The area of interest is defined by the circle covering a total of $13,000,000$ square metre. The human settlement areas (labelled I and J) are enclosed in amber-colored polygon. The estimated size of the two areas of interest are presented in Table 4 . The table indicates that the area covered by human settlement at Oba Ile as at 2007 was $2,731,074$ sq. $\mathrm{m}$ which is $21.01 \%$ of the area of interest.

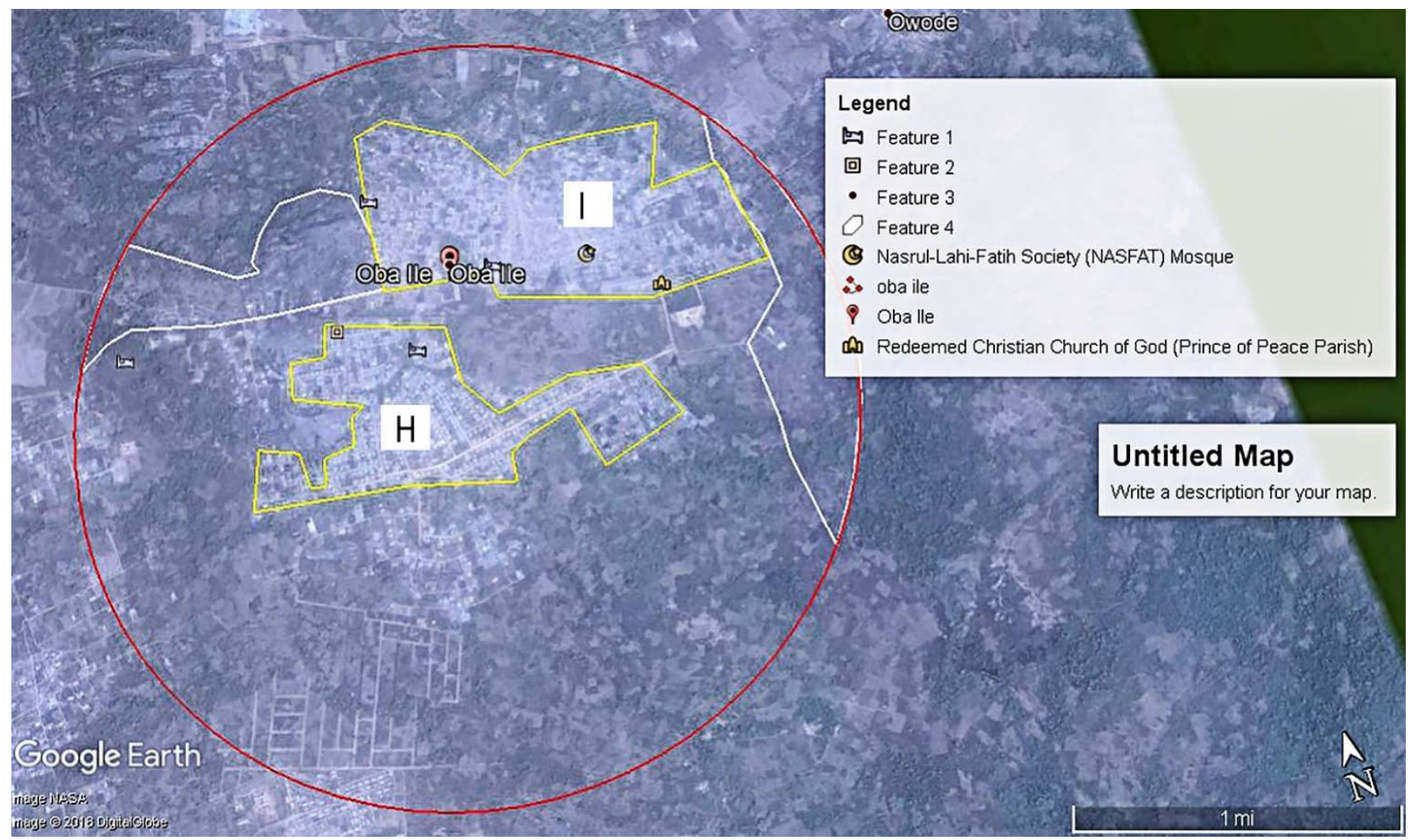

Source: Google Earth, 2018

Figure 4. Oba Ile showing horizontal settlement in 2007.

Table 4. Analysis of Human Settlement, Oba Ile, Akure (2007).

\begin{tabular}{lll}
\hline Description & No & Size (square metre) \\
\hline Total Area Sampled at Oba Ile & 1 & $13,000,000$ \\
Area H - Built up Area & 2 & $1,063,289$ \\
Area I - Built up Area & 3 & $1,063,289$ \\
Land area covered by human settlement & $(2+3)$ & $2,731,074$ \\
Percentage of built up area & {$[(2+3) / 1]^{*} 100$} & $21.01 \%$ \\
\hline
\end{tabular}

Source: Researcher's calculations, 2018.

\subsection{Oba Ile, Akure (2018)}

Figure 5 is the Google Earth image of Oba Ile as at 2018. The same area of interest in Figure 4 defined by the circle covering a total of $13,000,000$ square metre was covered. The areas devoid of human settlement (labelled $\mathrm{J}$ and $\mathrm{K}$ ) are separately enclosed and labelled. The rest of the encircled area was already occupied by human settlement; this area was estimated as the difference between the encircled area $(13,000,000$ sq. $\mathrm{m})$ and the polygons $\mathrm{J}$ and $\mathrm{K}$. Table 5 presents this analysis and it shows that the area covered by human settlement in 2018 was $11,576,880$ sq. m which is 
$89.05 \%$ of the area of interest.

Table 5. Analysis of Human Settlement, Oba Ile, Akure (2018).

\begin{tabular}{lll}
\hline Description & No & Size (square metre) \\
\hline Total Area Sampled at Oba Ile & 1 & $13,000,000$ \\
Area J - Un-built up area & 2 & 673,330 \\
Area K - Un-built up area & 3 & 749,790 \\
Land area covered by human settlement & $(1-(2+3))$ & $11,576,880$ \\
Percentage of built up area & {$[(1-(2+3)) / 1]^{*} 100$} & $89.05 \%$ \\
\hline
\end{tabular}

Source: Researcher's calculations, 2018.

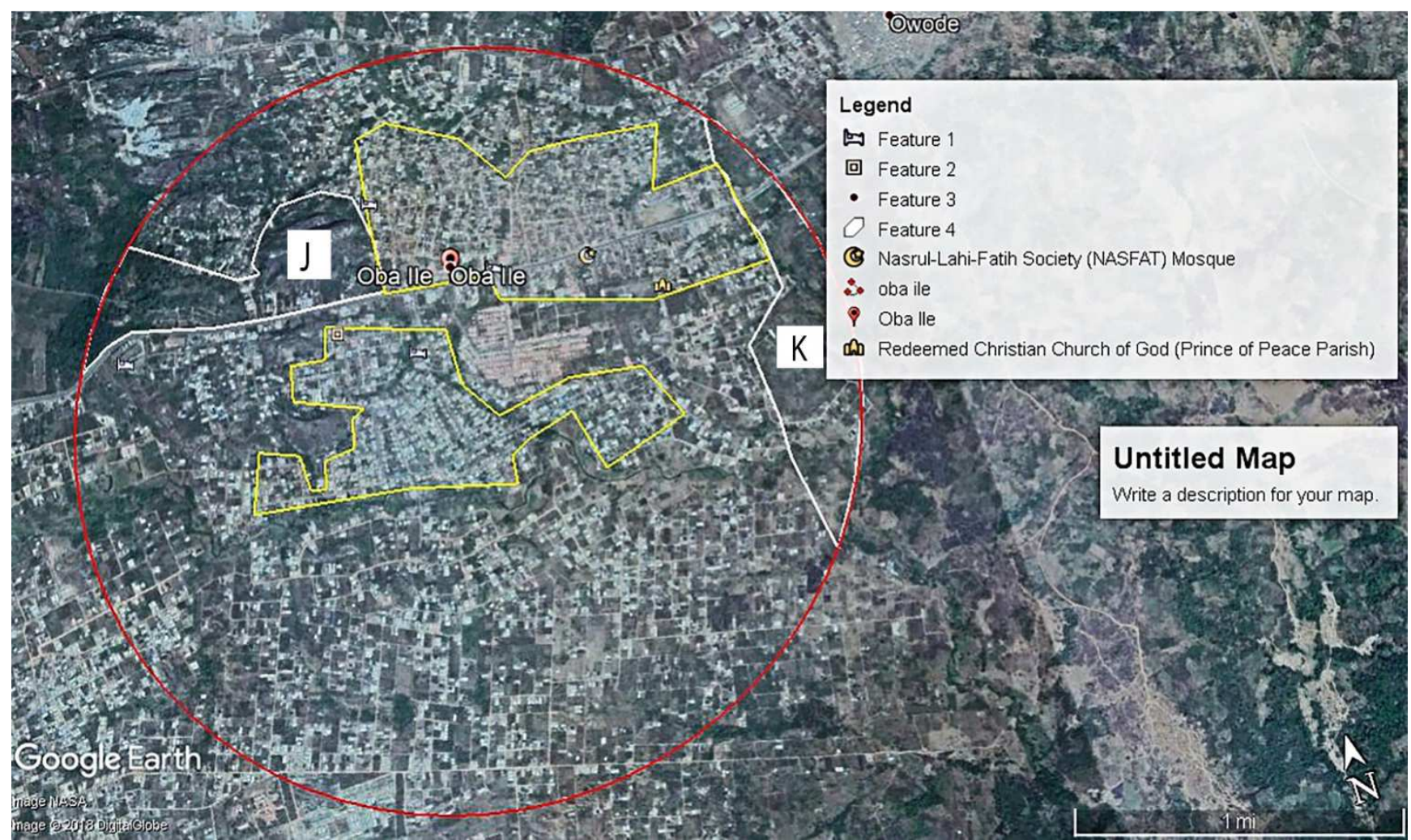

Source: Google Earth, 2018.

Figure 5. Oba Ile showing horizontal settlement in 2018.

\subsection{Horizontal Expansion in Oba Ile}

The total area sampled is $13,000,000$ sq. m; as at 2018 , a total of $11,576,880$ sq. $m$ has been built up as human settlement whereas the area built-up as human settlement in 2007 was $2,731,074$ sq. m. Thus, the horizontal expansion between 2007 and 2018 was 8,845,806 sq.m. The rate of horizontal expansion of human settlement at Oba Ile between 2007 and 2018 is $804,164.18$ sq. $\mathrm{m} / \mathrm{yr}$. Based on the projection of horizontal expansion in Table 6, by 2038 (20 years from 2018), horizontal expansion would have led to the conversion of additional 16,083,283.6 sq. $m$ into human settlement making a total of $27,660,163.6$ sq. $\mathrm{m}$ as human settlement. This is far in excess of the sampled area of $13,000,000$ sq. $\mathrm{m}$ at Oba-Ile. The implication of this is that most of the areas around Oba-Ile would be totally built up by 2038 if the current rate of horizontal expansion is maintained. Projected increase of horizontal expansion of human settlement for the next 32 years (that is 2050) is $25,733,253.76$ sq. $m$.

Table 6. Analysis of Horizontal Expansion, Oba Ile, Akure.

\begin{tabular}{lll}
\hline Description & No & Size (square metre) \\
\hline Total Area Sampled at Oba Ile & 1 & $13,000,000$ \\
Land area covered by human settlement in 2007 & 2 & $2,731,074$ \\
Land area covered by human settlement in 2018 & 3 & $(3-2)$ \\
Horizontal expansion of human settlement between 2007 and 2018 & $8,845,806$ & $((3-2) / 11 \mathrm{yrs})$. \\
Rate of horizontal expansion of human settlement at Oba Ile between 2007 and 2018 & $804,164.18$ sq. m/yr. \\
\hline
\end{tabular}




\begin{tabular}{lll}
\hline Description & No & Size (square metre) \\
\hline Rate of horizontal expansion of human settlement at Oba Ile between 2007 and 2018 & 4 & $804,164.18$ sq. m/yr. \\
Projected increase of horizontal expansion of human settlement for the next 20 yrs. (that is 2038) & $(4 * 20$ yrs.) & $16,083,283.6$ \\
Projected increase of horizontal expansion of human settlement for the next 32 yrs. (that is 2050) & $(4 * 32$ yrs.) & $25,733,253.76$ \\
\hline
\end{tabular}

Source: Researcher's calculations, 2018.

\subsection{FUTA North Gate, Akure (2007)}

Figure 6 is the Google Earth image of FUTA North gate as at 2007. The area of interest is defined by the circle covering a total of 13,000,000 square metre. The human settlement areas (labelled L, M, N and $\mathrm{O}$ ) are enclosed in amber-colored polygon. The estimated size of the four areas of interest are presented in Table 7. The table indicates the area covered by human settlement at the FUTA North Gate as at 2007 was 331,846 sq. $\mathrm{m}$ which is $2.55 \%$ of the area of interest.

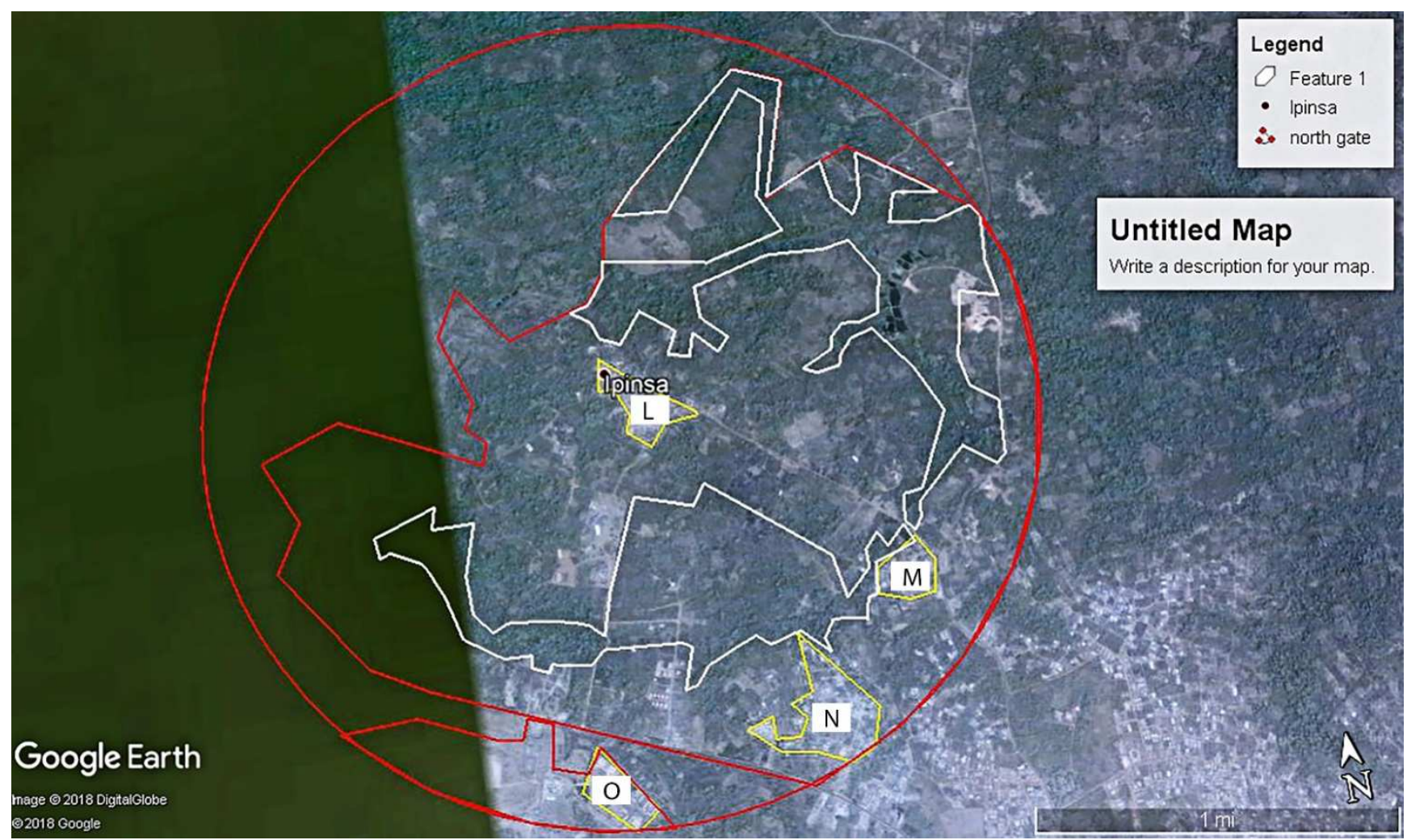

Source: Google Earth, 2018.

Figure 6. FUTA North Gate showing horizontal settlement in 2007.

Table 7. Analysis of Human Settlement, FUTA North Gate, Akure (2007).

\begin{tabular}{lll}
\hline Description & No & Size (square metre) \\
\hline Total Area Sampled at North Gate FUTA & 1 & $13,000,000$ \\
Area L - Built up Area & 2 & 76,853 \\
Area M - Built up Area & 3 & 57,737 \\
Area N - Built up Area & 4 & 140,981 \\
Area O - Built up Area & 5 & 56,275 \\
Land area covered by human settlement & $(2+3+4+5)$ & 331,846 \\
Percentage of built up area & {$[(2+3+4+5) / 1]^{*} 100$} & $2.55 \%$ \\
\hline
\end{tabular}

Source: Researcher's calculations, 2018.

\subsection{North Gate FUTA, Akure (2018)}

Figure 7 is the Google Earth image of FUTA South Gate as at 2018. The same area of interest in Figure 6 defined by the circle covering a total of $13,000,000$ square metre was covered. The human settlement areas (labelled P and Q) are enclosed in red-colored polygon. Inside the polygon $\mathrm{P}$, two areas without human settlement (labelled $\mathrm{R}$ and $\mathrm{S}$ ) are enclosed. Table 8 presents this analysis and it shows that the area covered by human settlement in 2018 was $6,074,074$ sq. 
$\mathrm{m}$ which is $46.72 \%$ of the area of interest.

Table 8. Analysis of Human Settlement, FUTA North Gate, Akure (2007).

\begin{tabular}{lll}
\hline Description & No & Size (square metre) \\
\hline Total Area Sampled at North Gate FUTA & 1 & $13,000,000$ \\
Area P - Built up Area with un-built up areas embedded & 2 & $7,876,035$ \\
Area Q - Built up Area & 3 & 365,822 \\
Area R - Un-built up area & 4 & $1,259,686$ \\
Area S - Un-built up area & 5 & 908,062 \\
Land area covered by human settlement & $((2+3)-(4+5))$ & $6,074,074$ \\
Percentage of built up area & {$[((2+3)-(4+5)) / 1]^{*} 100$} & $46.72 \%$ \\
\hline
\end{tabular}

Source: Researcher's calculations, 2018.

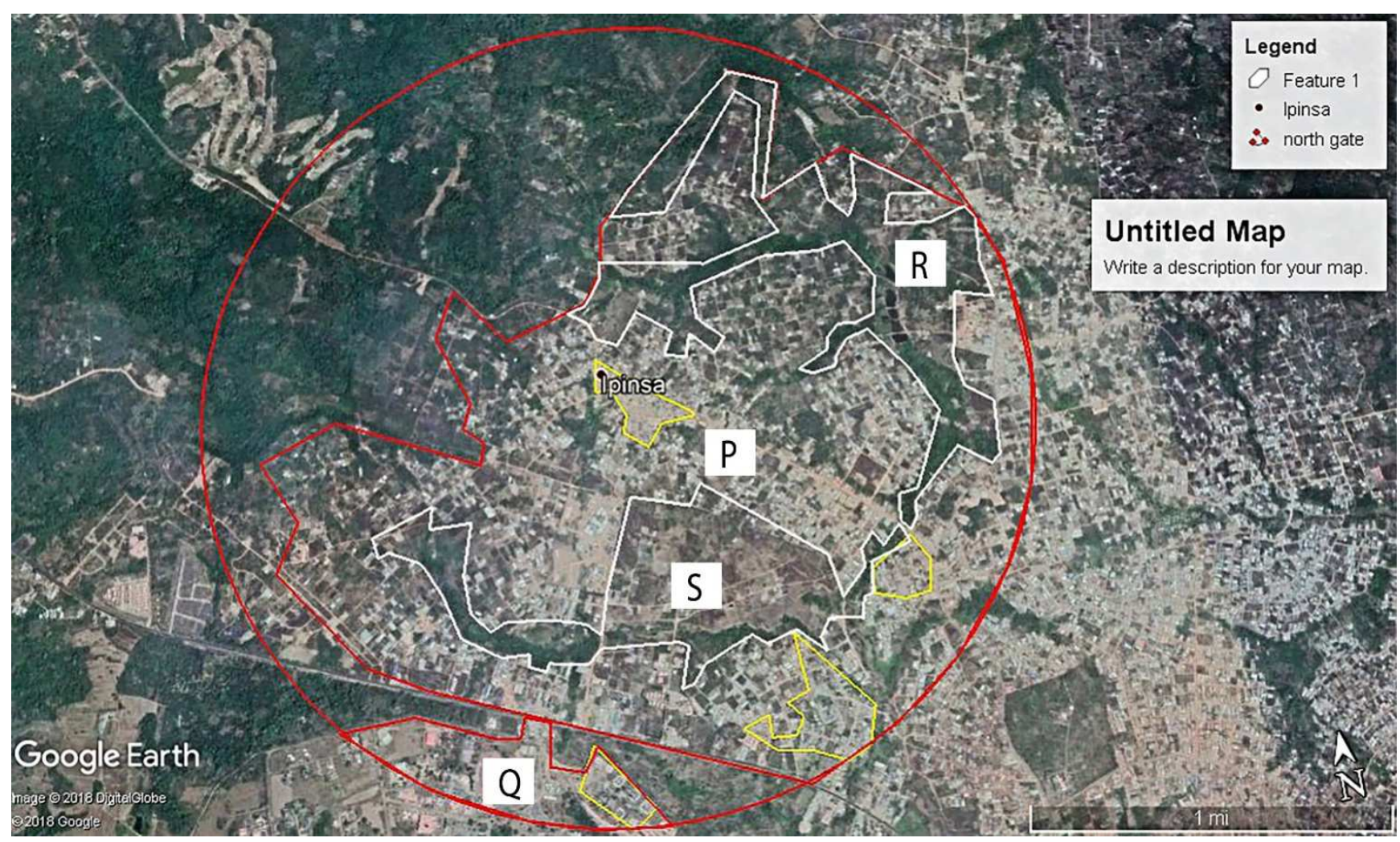

Source: Google Earth, 2018.

Figure 7. FUTA North Gate showing horizontal settlement in 2018.

\subsection{Horizontal Expansion in FUTA North Gate}

The total area sampled is $13,000,000$ sq. $\mathrm{m}$; as at 2018 , a total of $6,074,074 \mathrm{sq}$. $\mathrm{m}$ has been built up as human settlement whereas the area built-up as human settlement in 2007 was 331,846 sq.m. Based on the projection of horizontal expansion in Table 9, by 2038 (20 years from 2018), horizontal expansion would have led to the conversion of additional 10,440,414.4 sq. m into human settlement making a total of $16,514,488.4$ sq. $\mathrm{m}$ as human settlement. This is far in excess of the sampled area of $13,000,000 \mathrm{sq} . \mathrm{m}$ at FUTA North Gate. The implication of this is that the area around the FUTA North Gate would be totally built up by 2038 if the current rate of horizontal expansion is maintained. Projected increase of horizontal expansion of human settlement for the next 32 years (that is 2050) is $16,704,663.04$ sq. m.

Table 9. Analysis of Horizontal Expansion, FUTA North Gate, Akure.

\begin{tabular}{lll}
\hline Description & No & Size (square metre) \\
\hline Total Area Sampled at North Gate FUTA & 1 & $13,000,000$ \\
Land area covered by human settlement in 2007 & 2 & 331,846 \\
Land area covered by human settlement in 2018 & 3 & $6,074,074$ \\
Horizontal expansion of human settlement between 2007 and 2018 & $(3-2)$ & $5,742,228$ \\
Rate of horizontal expansion of human settlement at North Gate FUTA between 2007 and 2018 & $((3-2) / 11$ yrs.) & $522,020.72$ sq. m/yr. \\
\hline
\end{tabular}




\begin{tabular}{lll}
\hline Description & No & Size (square metre) \\
\hline Rate of horizontal expansion of human settlement at North Gate FUTA between 2007 and 2018 & 4 & $522,020.72$ sq. m/yr. \\
Projected increase of horizontal expansion of human settlement for the next 20 yrs. (that is 2038) & $(4 * 20$ yrs. $)$ & $10,440,414.4$ \\
Projected increase of horizontal expansion of human settlement for the next 32 yrs. (that is 2050) & $(4 * 32$ yrs.) & $16,704,663.04$ \\
\hline
\end{tabular}

Source: Researcher's calculations, 2018.

From the above results and from the images captured from Google earth the following conclusions can be made:

1. The built up area in Akure is gradually expanding.

2. As a result of horizontal expansion of settlement large natural vegetation had to give way. Vegetation like cocoa farms, and the likes had been cut down during the construction process of buildings.

3. From the projections made, it is clear that at the various rates of horizontal expansion of human settlement, by 2038 for South Gate FUTA would have expanded by $9,866,721.81$ sq. m, Oba Ile would have expanded by $16,083,283.6$ sq. $m$ and North Gate FUTA would have expanded by $10,440,414.4$ sq. $\mathrm{m}$.

4. Also, from the projections made, it is clear that at the various rates of horizontal expansion of human settlement, by 2050 for South Gate FUTA would have expanded by $15,786,754.88$ sq. m., Oba Ile would have expanded by $25,733,253.76$ sq. m. m and North Gate FUTA would have expanded by 16,704,663.04 sq. m.

5. Apart from the increase in horizontal expansion of these areas, there has been an increase in the density of these areas. This is particularly obvious in the images for South Gate FUTA.

6. The results confirm the predictions made by [15], at the current expansion rate Akure is growing into a fully grown conurbation.

7. The overall implications of the above is that town planning authorities needs to develop plans for orderly growth of human settlements that will be beneficial to Akure in particular and Ondo State in general. In addition, there is a need to provide for agricultural lands that will supply Akure city with food, especially vegetables which are better cultivated close to places of consumption. In summary, adequate planning and control of land use to ensure harmonious development and functional efficiency of human settlements are required.

\section{A Looming Crisis in Land Utilization}

A problem is looming in Nigeria which is a typical African country; this problem will arise from increasing building construction in small modular units and continuous horizontal expansion of human settlements, thus depleting natural vegetation areas which should be preserved for Agriculture and maintenance of the environment. The census exercise carried out in 1963 put Nigeria's population then at 55.6 million, the 1991 census put Nigeria's population at 88.9 million, while that of 2006 put Nigeria's population at 140.4 million [19]. The National Population Commission and National Bureau of Statistics estimates, puts the forecast of
Nigeria's population for 2016 at 193.3 million [4]. According to [5] Nigeria's population is bound to double within 20 years and increase three-fold by 2050 if Nigeria continues to grow at a $3.2 \%$ rate of the last census. With increasing population in Nigeria, there has been increasing expansion of human settlements, construction of houses for living, and other structures without adequate planning of the land use system and proper consideration for sustainable development.

Table 10 shows Nigeria's total land area which is a fixed resource; the population however has been increasing rapidly over time. As Nigeria's population increases the land per capital keeps on reducing. As at 1960, Nigeria with a population of $45,137,812$ million people had a land per capital area of 2.05 hectares. The land area per capital has since fallen from 2.05 hectares in 1960 to 0.48 hectares in 2017. The implication is that as at 2017 , only 0.48 hectares was available to each Nigerian if we were to divide the land evenly to all residents (Table 10). It is from these 0.48 hectares that each person would farm, build and carry out all the activities needed for his survival. In the next 20 years Nigeria's population is expected to double, thus bringing the land area per capital to 0.24 hectares. To continue to expand horizontally for settlement purposes is therefore not sustainable.

Table 10. Land Area, Population and Land Area per Capita in Nigeria.

\begin{tabular}{llll}
\hline Year & ${\text { Land area }(\mathrm{Ha})^{(\mathbf{1})}}$ & Population $^{(\mathbf{2})}$ & Land area per capita $(\mathrm{Ha})$ \\
\hline 1960 & $92,376,800$ & $45,137,812$ & 2.05 \\
1970 & $92,376,800$ & $55,981,400$ & 1.65 \\
1980 & $92,376,800$ & $73,460,724$ & 1.26 \\
1990 & $92,376,800$ & $95,269,988$ & 0.97 \\
2000 & $92,376,800$ & $122,352,009$ & 0.76 \\
2010 & $92,376,800$ & $158,578,261$ & 0.58 \\
2015 & $92,376,800$ & $181,181,744$ & 0.51 \\
2016 & $92,376,800$ & $185,989,640$ & 0.50 \\
2017 & $92,376,800$ & $190,886,311$ & 0.48 \\
\hline
\end{tabular}

Source: [20]

Availability of land for settlement is not the only problem arising from Nigeria's rapid population growth; it poses a threat to economic growth and agricultural development [19]. Nigeria's population is projected to increase but agricultural production is decreasing [21], this is partly due to increase in pressure on agricultural land for residential settlement. The rapid population growth in Nigeria impedes the provision of basic infrastructure [19] and increases the demand for natural resources like water [21]. Nigeria is one of the counties suffering from water stress, with expected change in climate and continuous populating growth, water shortage is likely to become acute [21]. 
Migration, both international and internal migration, is already prevalent in Nigeria, with increasing population it is bound to increase. Projections show that 100 million people will be living in urban centers by 2020 in Nigeria [22]; and $75 \%$ of Nigeria's population will live in urban centers by 2050 [21]. This will however increase the poverty rate and traffic congestion in the urban centers if appropriate approach is not deployed to mitigate the situation., especially because over $60 \%$ of urban settlers live in informal settlements [21].

Energy consumption, carbon emission and air pollution are other sectors that will seriously feel the effect of Nigeria's population increase [23]. According to [23]; Nigeria's energy consumption rose from 0.42 Quadrillion Btu (Quads) in 1980 to approximately 0.92 quads in 2001. Already in Nigeria the energy demand far outstrips the supply, less than $40 \%$ of the country is connected to the national grid [24]. Households and commercial buildings rely on diesel powered generators to complement the energy supply from the national grid; this contributes immensely to the carbon emission in the nation. It is therefore necessary to look for sustainable alternatives to diesel powered engines in terms of power generation. One of the possible solutions therefore is the design and construction of buildings which are self-sustainable and can support the surrounding buildings with respect to energy supply; and water and sanitation. Thus, contributing to Africa's aspiration for a prosperous continent based on inclusive growth and sustainable development

\section{Conclusion}

It is evident from the research that Nigeria's horizontal expansion rate of human settlement is not sustainable on a long term basis. This is because as in a few years everywhere will be built up thus leading to more problems like urban flooding resulting from the absence of open spaces and soft landscaping to absorb rain water, heat island effect, increase in $\mathrm{CO}_{2}$ emission as a result of absence of sufficient green to make use of it and release fresh oxygen into the environment. With increase in $\mathrm{CO}_{2}$, climate change phenomenon will be further aggravated; the local climatic variables in Nigeria will not be spared of the negative consequences. Also with everywhere built up there will be little or no land for agricultural practices, thus there will be increase in the hunger and poverty level as food will no longer be produced locally; prices of food will increase and the value of Nigeria's naira may fall given that most of the food that will be consumed will be imported.

This calls for the adoption of the more sustainable alternative; sustainable high-rise mixed-use buildings which would solve a variety of problems; problems such as housing for the increasing population, reduction of the number of vehicles on the roads, thus reducing traffic congestion in Nigerian cities and the emission of greenhouse gases, reduction in the depletion of vegetative cover and agricultural land thus enabling the production of food for the increasing population. Buildings which conserves water and recycles it would help alleviate the already existing water stress in the nation. Buildings that generate part of the energy it needs as well as conserves energy would help to improve the existing poor state of energy supply in Nigeria.

\section{References}

[1] FMH \& UD. (2006). Sustainable Human Settlements Development. Abuja: Federal Ministry of Housing and Urban Development.

[2] Owei, O. B., Obinna, V. C., \& Ede, P. N. (2010). The challenges of sustainable land use planning in Nigerian cities the case of Port Harcourt. Port Harcourt: 46th ISOCARP Congress.

[3] World Commission on Environment and Development. (1987). Our common future. Oxford: Oxfor university press.

[4] National Population Commission and National Bureau of Statistics Estimates. (2018). Demographic statistics bulletin.

[5] Factsheet. (2017). Nigeria Population and Development. Health pulicy plus. doi: http://www.healthpolicyplus.com/ns/pubs/71497266_HPPlusNigeriaRAPIDOnePageFactSheetJuly.pdf

[6] Roy, P. S., \& Roy, A. (2010). Landuse and land cover change in India: Aremote sensing \&GIS prespective. Journal of the Indian Institute of Science, 489-501.

[7] Duhamel, C. (2009). Land use and land cover, including their classification. Land use, land cover and soil sciences, 80-89.

[8] Ellis, E. (n.d.). Land-Use and Land-Cover Change. Retrieved from The Encyclopedia of Earth: http://www.eoearth.org/view/article/154143/

[9] Balasubramanian, A. (2015). Human settlement systems. Retrieved from https://www.researchgate.net/publication/310021451_HUMA N_SETTLEMENT_SYSTEMS

[10] Overseas Development Institute. (n.d.). Human settlements and their place in development. Retrieved from https://www.odi.org/sites/odi.org.uk/files/odiassets/publications-opinion-files/6608.pdf

[11] Kasim, O. F., Agbola, B., \& Coker, M. O. (2014). Dynamics of land use and land cover in Ibadan region, Nigeria. Retrieved from https://www.researchgate.net/publication/320696289_Dynamics_of _Land_Use_and_Land_Cover_Change_in_Ibadan_Region_Nigeria

[12] Enoguanbhor, E. C., Gollnow, F., Nielsen, J. O., Lakes, T., \& Walker, B. B. (2019). Land cover change in the Abuja cityregion, Nigeria: Integrating GIS and remotely sensed data to support land use planning. Sustainability, 11 (5). doi: http://dx.doi.org/10.3390/su11051313

[13] Atubi, A. O., Awaritefe, D. O., \& Toyon, A. B. (2018). Analysis of land use and land cover change characteristics in Warri metropolis, Nigeria. International Journal of Development and Sustainabilit, 7 (3), 1143-1168.

[14] Kanayochukwu, E. C., Daful, M. G., \& Umeano, E. C. (2019). Land-use and land-cover analysis of Kaduna south local government area, Kaduna state, Nigeria. American Journal of Environmental Protection, 8 (3), 62-71. doi: 10.11648/j.ajep.20190803.11. 
[15] Owoeye, J. O., \& Ibitoye, O. A. (2016). Analysis of Akure urban land use change detection remote imagery perspective. Urban Studies Research. Retrieved from http://dx.doi.org/10.1155/2016/4673019

[16] Malarvizhi, K., Kumar, S. V., \& Porchelvan, P. (2016). Use of high Resolution Google earth satellite imagery in landuse map preparation for urban related applications. Procedia Technology (pp. 1835 - 1842). Elsevier.

[17] Adi, W., Khairulmaini, O. S., Sitanala, F., \& Jarot, M. S. (2016). Spatial temporal land use change detection Using google earth data. IOP Conf. Series: Earth and Environmental Science 47. IOP. doi: 10.1088/1755-1315/47/1/012031.

[18] Oriye, O., \& Fakere, Y. (2015). Urban land use in the city of Akure, Nigeria. Ethiopian Journal of Environmental Studies \& Management, 471-483. https://doi.org/10.4314/ejesm.v8i5.1

[19] Ifatimehin, O. O., Oluwagbemi, T., \& saliu, O. J. (https://www.funai.edu.ng/wp-content/uploads/2017/03/Ananalysis-of-population-growth-and-sustainable-agricultural-
production-in-Nigeria-Ifatimehin oluwagbemi Saliu.pdf). An analysis of population growth $\overline{\text { and }}$ sustainable agricultural production in Nigeria. Anyigba: Kogi state University.

[20] Oguntade, A. E. (2018). Land administration and agricultural transformation. Abuja: Nation Stakeholders Dialogue on Land Reform in Ngeria.

[21] Ogunbiyi, B. (2012). Nigeria: Population and Demographic trends. Washington DC: The Woodrow Wilson International Center for Scholars.

[22] Oyewole, O. I. (2013). Challenges of Urbanization and Urban Growth in Nigeria. American Journal of Sustainable Cities and Society, 1 (2), 79-95.

[23] Science Alert. (2006). The effect of population growth in Nigeria. Journal of Applied Sciences, 6 (6), 1332-1337.

[24] Akinboro, F. G., Adejumobi, L. A., \& Makinde, V. (2012). Solar energy installation in Nigeria: observations, prospects, probelems and solution. Transnational Journal of Science and Technology, 2 (4), 73-84. 